Original article

\title{
GENOMIC IDENTIFICATION OF BORDER DISEASE VIRUS IN SHEEP ABORTED FOETUSES
}

\author{
A. MOKHTARI \& M. MANSHOORI \\ Department of Pathobiology, Faculty of Veterinary Medicine, \\ University of Shahrekord, Shahrekord, Iran
}

\begin{abstract}
Summary
Mokhtari, A. \& M. Manshoori, 2018. Genomic identification of Border disease virus in sheep aborted foetuses. Bulg. J. Vet. Med., 21, No 3, 358-363.

Border disease is a congenital viral disease of sheep and goats and cause significant economic losses worldwide. It may cause abortion in sheep. However, there isn't any report of ovine abortion due to this virus from Iran. The aim of the present study was to investigate the role of this viral infection in sheep abortions in Chaharmahal and Bakhtiari province. To this end, 100 samples of aborted sheep foetuses were tested with RT-PCR. Nine $(9 \%)$ sheep were determined to be BDV positive. It was concluded that BDV was involved in abortions in sheep population in Chaharmahal and Bakhtiari, Iran.
\end{abstract}

Key words: abortion, Border disease virus, Iran, RT-PCR, sheep

\section{INTRODUCTION}

Pestiviruses infect sheep, cattle and pigs, and cause significant economic losses worldwide. Border disease virus (BDV) belongs to the genus Pestivirus within the family Flaviviridae (Krametter-Froetscher et al., 2007; Kale et al., 2011). Border disease is a congenital viral disease of sheep and goats which was first reported in 1959 in the Border region of Wales and England (Hughes et al., 1959). The disease is characterised by barren ewes, abortion, stillbirth and the birth of small, weak lambs showing tremor, abnormal body conformation and hairy fleeces (Nettleton et al., 1998).
Among the natural hosts of pestivirus are ruminants and wild ruminants in addition to various single-toed animals and deer (Moennig et al., 1990).

BDV can be transmitted through the secretions and excretions of the infected animals in addition to aborted foetuses, foetal membranes, and infected blood (Kittelberger et al., 2008).

The pestivirus genome is ssRNA+ that is $12.3-12.7$ kilobases $(\mathrm{kb})$. The virus, $40-60 \mathrm{~nm}$ in diameter, is surrounded by a 5-7 $\mu \mathrm{m}$ thick membrane whose outer surface is lined with radial processes, characterised by helical symmetry (Rasmussen et al., 2008). The virus is inactivated at 
$56{ }^{\circ} \mathrm{C}$ for $30 \mathrm{~min}$ and is sensitive to lipid solvents, ultraviolet light, and disinfectants (Rumenapf et al., 1991). Two biotypes of pestiviruses have been distinguished according to their proliferation in the cell culture - cytopathic and noncytopathic (Fulton et al., 2005). BDV is further divided into 4 subgroups in accordance with its antigenic features and host species (Berriatua et al., 2006). Besides these subgroups, 2 novel subgroups (BDV5 and BDV6) were established from pestivirus isolates in France (Dubois et al., 2008).

Serological investigations have shown a worldwide distribution of Border disease virus. Seroprevalence rates in sheep vary from 5 to $50 \%$ depending on country or region investigated (Nettleton et al., 1998). Serological investigations in Iran have shown a mean individual prevalence of $16 \%$ with marked differences (Dadkhah et al., 2011). Based on recent reports, BDV isolates have been divided into seven genotypes at least, and widely distributed in different countries, such as many European countries, Australia, New Zealand, Canada, the United States, India, Turkey, Japan and China (Oguzoglu et al., 2009; Strong et al., 2010; Mao et al., 2015). Unfortunately, there isn't any report of ovine abortion due to this virus from Iran. Therefore, the aim of the present study was to characterise the presence of BDV genome in sheep aborted foetuses.

\section{MATERIALS AND METHODS}

\section{Blood sampling and RNA extraction}

The target group of this cross-sectional survey comprised aborted samples of sheep taken by personnel of the veterinary organisations of Chaharmahal and Bakhtiari province. The foetal fluids were obtained during the period 2014-2015 and were analysed to detect BDV gene. The number of sheep in this province was approximately 240,000 and the number of affected farms was 851 .

Foetal fluids were collected with a syringe and then immersed in Eagle's minimal essential medium supplemented with penicillin, amikacin, amphotericin $\mathrm{B}$ and $1 \%$ foetal bovine serum. RNA was extracted with QIAamp Viral RNA Mini Kit (Qiagen, Cat No: 52904) according to manufacturer's instruction.

\section{Detection of BDV by RT-PCR assay}

TaqMan Reverse Transcription Kit (Invitrogen, Cat No: N8080234) was used to cDNA synthesis. In brief, the reaction was done in the total volume of $10 \mu \mathrm{L}$ and included $1 \mu \mathrm{L}$ of $10 \times$ RT buffer, $2.2 \mu \mathrm{L}$ of $25 \mathrm{mM} \mathrm{MgCl} 2,2 \mu \mathrm{L}$ of $10 \mathrm{mM}$ dNTPs, $0.5 \mu \mathrm{L}$ of Random hexamers, $0.2 \mu \mathrm{L}$ of RNase inhibitors, $0.25 \mu \mathrm{L}$ of reverse transcriptase (MMLV RT) $(50 \mathrm{U} / \mu \mathrm{L})$, the RNA template $(400-500 \mathrm{ng} / \mu \mathrm{L})$ and deionised sterile water. RT reaction thermal cycling conditions consisted of: $25^{\circ} \mathrm{C}$ for $10 \mathrm{~min}, 48{ }^{\circ} \mathrm{C}$ for $30 \mathrm{~min}$ and $95{ }^{\circ} \mathrm{C}$ for 5 min. Then cDNAs were maintained at -20 ${ }^{\circ} \mathrm{C}$ for PCR assay. The presence of BDV was detected using the primers designed by Beacon designer software. The sequences of the forward and reverse primers were 5'- TCGTGGTGAGATCCCT GAG-3' and 5'- GCAGAGATTTTTTAT ACTAGCCTATRC-3', respectively. Each PCR reaction was performed in a final volume of $25 \mu \mathrm{L}$ containing $11 \mu \mathrm{L}$ of deionised sterile water, $10 \mu \mathrm{L}$ of Taq DNA Polymerase $2 \times$ Mix Red- $\mathrm{MgCl}_{2} 2 \mathrm{mM}$ (GeneAll, Cat. No: A180301), 1 pmol of each primer and $2 \mu \mathrm{g}$ of DNA template.

The thermal cycling conditions for the PCR amplification were 1 cycle for $4 \mathrm{~min}$ at $94{ }^{\circ} \mathrm{C}, 35$ cycles of $30 \mathrm{~s}$ at $94{ }^{\circ} \mathrm{C}, 45 \mathrm{~s}$ at 
$55{ }^{\circ} \mathrm{C}$ and $45 \mathrm{~s}$ at $72{ }^{\circ} \mathrm{C}$, with a final extension step of $5 \mathrm{~min}$ at $72{ }^{\circ} \mathrm{C}$. Positive and negative controls (from Veterinary Laboratories Agency, UK) were included in each analysis. Six $\mu \mathrm{L}$ of the amplified products were loaded on a $1.3 \%$ agarose gel and visualised by staining with ethidium bromide and compared to DNA markers (100 base pair ladder, Fermentas).

\section{Sequencing}

Two PCR positive samples in a volume of $50 \mathrm{~mL}$ were sent to Bioneer Company for sequencing. DNA Sequencing Service performed on the ABI 3730XL DNA Analyzer, which provides high quality of sequence analysis data (Phred Score $(\mathrm{QV}): \geq 20$, guaranteed read lengths: $\geq 600 \mathrm{bp}$ ). After sequencing, alignment of expected amplicon with the read sequences was performed to confirm PCR accuracy.

\section{RESULTS}

BDV gene fragment was identified using RT-PCR test and the BDV-specific band with the size of $225 \mathrm{bp}$ was detected in DNA positive control. The positive RTPCR products were of the same size as those from the positive control (Fig. 1). Of 100 foetal fluids, 9 samples (9\%) were positive for BDV nucleotide fragment using RT-PCR test.

After sequencing, alignment of expected amplicon with the read sequences, confirmed the presence of the BDV nucleotide fragment in the positive samples. There was $99 \%$ identity between PCR product sequences and expected amplicon that showed that nucleotide fragment amplification was done correctly (Fig. 2).

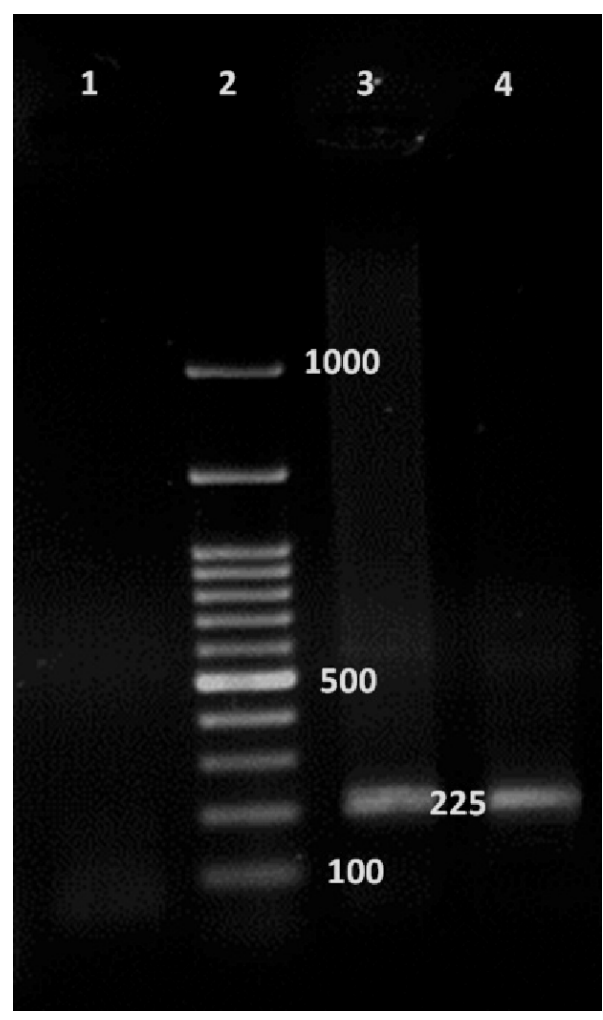

Fig. 1. Electrophoresis of BDV RT-PCR amplification products. Lane 1: negative control, lane 2: 100bp DNA ladder, lane 3: positive control, lane 4: positive sample.

\section{DISCUSSION}

Although the presence of pestivirus infections in animal populations can be determined using direct immunofluorescence and IP, its antigens can be detected using ELISA (Sandvik et al., 2005). However, when the sensitivity and specificity of these tests are considered, ELISA is not efficient, and the use of RT-PCR is firmly suggested to detect BDV antigens (Garcia-Perez et al., 2009).

Previous studies (Krametter-Froetscher et al., 2008) made clear that Border disease virus infected sheep are at a high 


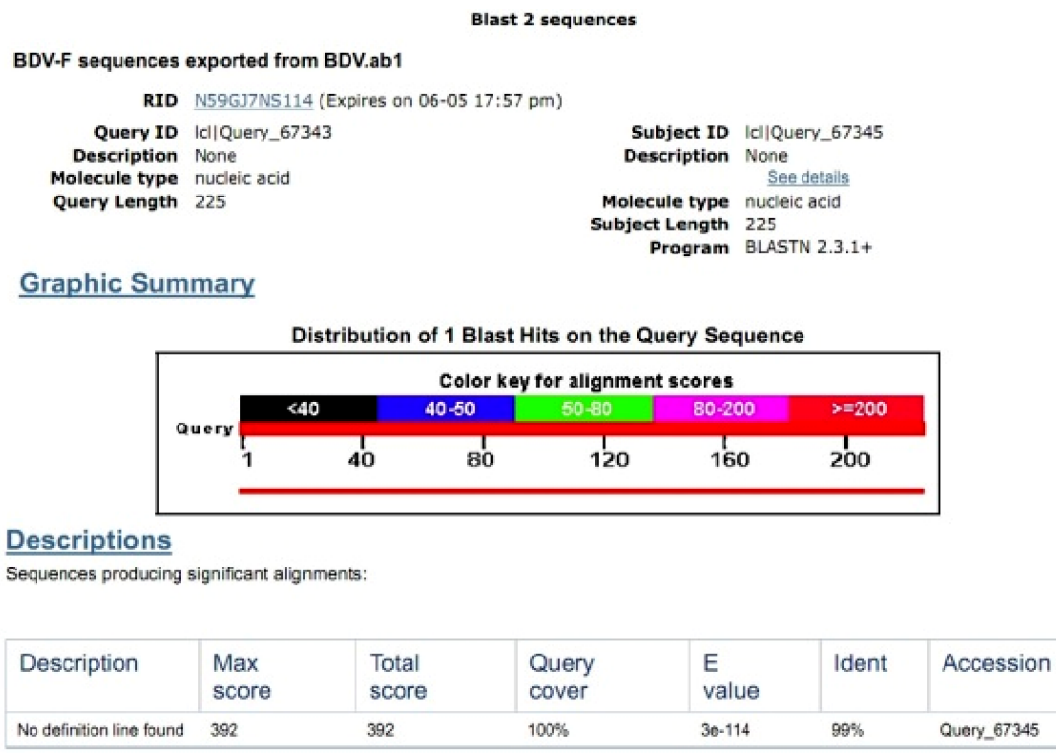

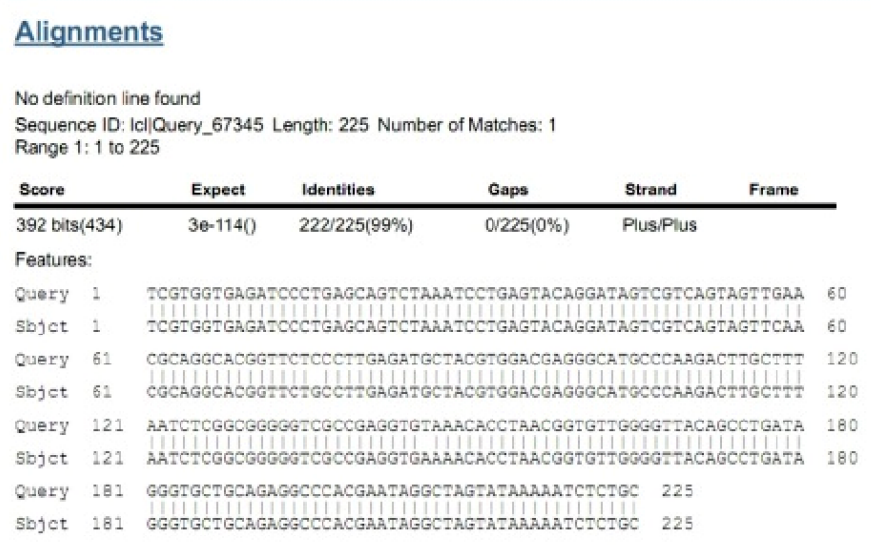

Fig. 2. Alignment of reading sequence of BDV RT-PCR products with the expected amplicon confirming 99\% identity between PCR product sequences and expected amplicon.

risk for pestivirus introduction in susceptible cattle herds and cause abortion in sheep and goats.

The presence of pestiviruses in rams has been investigated previously in Turkey (Burgu et al., 2001). BDV infection in goats occurred in China; however, no cases of $\mathrm{BD}$ have been reported in sheep flocks. Liu et al. (2013) demonstrated that BDV also infected sheep in China. These reports showed the low prevalence found in rams that can be explained by the management conditions, because in some flocks, rams are reared in a separate group and consequently maintained far from infected animals. Keyvanfar et al. (1999) showed by serum neutralisation test using Border disease virus (isolated from Iran) a BDV prevalence of $12.8 \%$. According to the age, the lambs between 4-8 months 
showed the lowest $(8.1 \%)$ and those over 18 months had the highest $(18.3 \%)$ infection rate. In another report from Iran, Dadkhah et al. (2011) found that $16 \%$ of the studied samples were infected by the virus and had a distinctive antibody titre.

There isn't any report of ovine abortion due to this virus from Iran and the present study is the first, to our knowledge, to examine the BDV prevalence of aborted sheep foetuses living in Chaharmahal and Bakhtiari province of Iran. It is useful for future studies in this area.

In the present study, 9 aborted foetuses positive for the presence of BDV gene were found. The result of PCR was confirmed by sequencing that showed that there was $99 \%$ identity between PCR product sequences and expected amplicon. DNA sequencing has become a key technology in many areas of biology and other sciences. In this study DNA sequencing may be used to determine the sequence of individual genes of BDV strains in Iran.

It is suggested that all animals of the breed stock should be checked for the presence of BDV. To control BDV in a flock, it is also important to ensure that replacement lambs are all negative for BDV.

Hairy shaker lambs only appear in some breeds of sheep, depending on the characteristics of their wool. There are other common clinical symptoms such as stillbirth, abortion, neurological symptoms, joint disorders, and bone malformations, which must be considered as well (Mao et al., 2015). Presence of BDV in wild animals should be checked in Iran, as well.

In conclusion, for the first time to our knowledge, the presence of BDV infection in sheep aborted foetuses in Chaharmal and Bakhtiari province was demon- strated, so BDV may be considered as an etiologic agent of sheep abortions in Iran.

\section{ACKNOWLEDGEMENTS}

The authors are grateful to microbiology laboratory personnel of the Faculty of Veterinary Medicine, University of Shahrekord, for their collaboration.

\section{REFERENCES}

Berriatua, E., J. F. Barandika, G. Aduriz, A. Hurtado, L. Estevez, R. Atxaerandio \& A. L. Garcia-Perez, 2006. Flock-prevalence of border disease virus infection in Basque dairy-sheep estimated by bulk-tank milk analysis. Veterinary Microbiology, 118, $37-46$.

Burgu, I., Y. Akca, F. Alkan, A. Ozkul, T. Karaoglu, S. Bilge-Dagalp, T. C. Oguzoglu \& K. Yesilbag, 2001. The serological and virological investigations and pathogenesis of BVDV infection in sheep during pre- and post-partum periods. Turkish Journal of Veterinary and Animal Sciences, 25, 551-557.

Dadkhah, M.A., M. Yeganehzad, F. Sarkarati \& B. Nadery, 2011. Serological evaluation of sheep Border disease in Sarab city, Iran. Journal of Animal and Veterinary Advances, 10, 1283-1286.

Dubois, E., P. Russo, M. Prigent \& R. Thiery, 2008. Genetic characterization of ovine pestiviruses isolated in France, between 1985 and 2006. Veterinary Microbiology, 130, 69-79.

Fulton, R. W., R. E. Briggs, J. F. Ridpath, J. T. Saliki, A. W. Confer, M. E. Payton, G. C. Duff, D. L. Step \& D. A. Walker, 2005. Transmission of bovine viral diarrhoea virus $1 \mathrm{~b}$ to susceptible and vaccinated calves by exposure to persistently infected calves. Canadian Journal of Veterinary Research, 69, 161-169.

Garcia-Perez, A. L., E. Minguijon, F. B. Jesus, G. Aduriz, I. Povedano, R. A. Juste \& A. 
Hurtado, 2009. Detection of Border disease virus in fetuses, stillbirths, and newborn lambs from natural and experimental infections. Journal of Veterinary Diagnostic Investigation, 21, 331-337.

Hughes, L. E. \& G. F. Kershaw, 1959. "B" or Border disease, an undescribed disease of sheep. The Veterinary Record, 71, 313-317.

Kale, M., S. Yavru, A. Ata, M. Kocamuftuoglu, O. Yapici \& S. Hasircioglu, 2011. Bovine viral diarrhoea virus infection in relation to fertility in heifers. Journal of Veterinary Medical Science, 73, 331-336.

Keyvanfar, H., F. Hemmatzadeh \& R. KargarMoakhar, 1999. A serological survey on prevalence of sheep Border disease in Iran. Journal of Veterinary Research, 54, 1-8.

Kittelberger, R. \& C. Pigott, 2008. The use of pestivirus antigen ELISA currently available for the detection of hairy shaker disease/border disease virus in sheep. New Zealand Veterinary Journal, 56, 343-344.

Krametter-Froetscher, R., H. Kohler, V. Benetka, K. Moestl, F. Golja, S. Vilcek \& W. Baumgartner, 2007. Influence of communal alpine pasturing on the spread of pestiviruses among sheep and goats in Austria: First identification of border disease virus in Austria. Zoonoses and Public Health, 54, 209-213.

Krametter-Froetscher, R., V. Benetka, K. Moestl \& W. Baumgartner, 2008. Transmission of Border Disease Virus from sheep to calves - a possible risk factor for the Austrian BVD eradication programme in cattle? Wiener Tierarztliche Monatsschrift, 95, 200-203.

Liu, X., L. Mao, W. Li, L. Yang, W. Zhang, J. Wei \& J. Jiang, 2013. Genome sequence of border disease virus strain JSLS12-01, isolated from sheep in China. Genome Announcements, 1, e00502-00513.

Mao, L., X. Liu, W. Li, L. Yang, W. Zhang \& J. Jiang, 2015. Characterization of one sheep border disease virus in China. Virology Journal, 12, 15.
Moennig, V., H. R. Frey, E. Liebler, J. Pohlenz \& B. Liess, 1990. Reproduction of mucosal disease with cytopathogenic bovine viral diarrhea virus selected in vitro The Veterinary Record, 127, 200-203.

Nettleton, P. F., J. A. Gilray, P. Russo \& E. Dlissi, 1998. Border disease of sheep and goats. Veterinary Research, 29, 327-340.

Oguzoglu, T. C., M. T. Tan, N. Toplu, A. B. Demir, S. Bilge-Dagalp, T. Karaoglu, A. Ozkul, F. Alkan, I. Burgu, L. Haas \& I. Greiser-Wilke, 2009. Border disease virus (BDV) infections of small ruminants in Turkey: A new BDV subgroup? Veterinary Microbiology, 135, 374-379.

Rasmussen, T. B., I. Reimann, B. Hoffmann, K. Depner, A. Uttenthal \& M. Beer, 2008. Direct recovery of infectious pestivirus from a full-length RT-PCR amplicon. Journal of Virological Methods, 149, 330-333.

Rumenapf, T., G. Meyers, R. Stark \& H. J. Thiel, 1991. Molecular characterization of hog cholera virus. Archives of Virology, Supplement, 3, 7-18.

Sandvik, T., 2005. Selection and use of laboratory diagnostic assays in BVD control programmes. Preventive Veterinary Medicine, 72, 3-16.

Strong, R., S. A. La Rocca, G. Ibata \& T. Sandvik, 2010. Antigenic and genetic characterisation of border disease viruses isolated from UK cattle. Veterinary Microbiology, 141, 208-215.

Paper received 24.06.2016; accepted for publication 25.11.2016

\section{Correspondence:}

A. Mokhtari

Department of Pathobiology,

Faculty of Veterinary Medicine,

University of Shahrekord,

P.O Box 115, Shahrekord, Iran, tel: +983832324427

fax: +9832324427

email: a.mokhtari@alumni.ut.ac.ir 